\title{
Benzo[a]pyrene sourcing and abundance in a Coal Region in Transition reveals historical pollution, rendering soil screening levels impractical.
}

Carlos Boente ( $\square$ carboente@gmail.com )

Universidad de Oviedo https://orcid.org/0000-0001-8266-828X

\section{Diego Baragaño}

Universidad de Oviedo

José Luis R. Gallego

Universidad de Oviedo

\section{Research}

Keywords: Soil pollution, Benzo[a]pyrene, Polycyclic aromatic hydrocarbons (PAHs), Soil Screening Levels

Posted Date: April 27th, 2020

DOI: https://doi.org/10.21203/rs.3.rs-22580/v1

License: (c) (i) This work is licensed under a Creative Commons Attribution 4.0 International License.

Read Full License

Version of Record: A version of this preprint was published at Environmental Pollution on November 1st, 2020. See the published version at https://doi.org/10.1016/j.envpol.2020.115341. 


\section{Abstract \\ Background}

Benzo[a]pyrene (BaP) is a hazardous compound for human health and for environmental compartments. Its transfer and deposition through the atmosphere affects soil quality. In this regard, soil screening levels are commonly used to monitor the degree of soil contamination. However, these thresholds are often established without considering historical anthropogenic activities that affect soil (diffuse pollution). In this context, this study had the following objectives: 1 ) to identify the potential pollutant load of BaP, as well as other Polycyclic Aromatic Hydrocarbons (PAHs), in the soil of an area in a prominent Coal Region in Transition in NW Spain; 2) to test whether soil screening levels are realistic and whether they reflect the complexity of regions closely linked to heavy industries and mining; and 3) to determine whether there is a relationship between PAHs and inorganic pollutants.

\section{Results}

The 150 soil samples studied showed a notable content of high molecular weight PAHs. In this regard, BaP surpassed the threshold levels in practically the entire area. Samples fell into groups: a first group of outliers statistically determined through robust Mahalanobis distance, and three more by means of hierarchical cluster analysis. PAH-parent diagrams revealed a relatively homogenous fingerprint for all clusters. In addition, molecular diagnostic ratios pointed to coal combustion as the main pollution source, whereas only a few of the outliers appeared to be related to specific spills. The BaP background was calculated to be $0.24 \mathrm{mg} \cdot \mathrm{kg}^{-1}$, exceeding the threshold limits established in Spain by more than 10 times. Finally, a factor analysis revealed a moderate correlation of $\mathrm{BaP}$ with elements usually associated with coal combustion, such as $\mathrm{TI}$ and $\mathrm{V}$.

\section{Conclusions}

The soils of regions associated with coal exploitation and heavy industry have an indelible pollution fingerprint, caused namely by $\mathrm{BaP}$ and other PAHs, which come to form part of the geochemical background. The use of official soil screening levels in such regions is therefore questionable, and hot points should be determined on the basis of soil backgrounds specifically calculated for these areas.

\section{Background}

Polycyclic Aromatic Hydrocarbons (PAHs) are a class of Semi-Volatile Organic Compounds (SVOCs) found pervasively in various environmental compartments, such as soils, water, air and sediments $[2,13$, 68]. In this regard, several studies have demonstrated that the number of humans exposed to PAHs through soils is higher than through air or water $[45,51,73]$. Given that these compounds are carcinogenic, mutagenic, teratogenic and toxic to all living organisms, there is a need to monitor their 
concentration in soils $[6,56]$. PAHs are listed as priority pollutants by the European Union and the United States Environmental Protection Agency [14, 20,55], and they are becoming increasingly studied and tracked in soils worldwide $[1,11,23,64]$.

PAHs are often divided into 16 priority compounds. Among them, benzo[a]pyrene $(\mathrm{BaP})$ is one of the most hazardous because of its carcinogenic and mutagenic properties and its persistence and bioaccumulation in the environment $[66,78]$. Consequently, the European Union established in 2004 an atmospheric target value of $1 \mathrm{ng} / \mathrm{m}^{3}$ for BaP [18]. Regarding soils, Spanish legislation set out Risk-Based Soil Screening Levels (RBSSLs) for organic contaminants, based on toxicity parameters and land use. In this regard, these limits for BaP in soils are: $2 \mathrm{mg} \cdot \mathrm{kg}^{-1}$ for industrial use; $0.2 \mathrm{mg} \cdot \mathrm{kg}^{-1}$ for urban use; and $0.02 \mathrm{mg} \cdot \mathrm{kg}^{-1}$ for other uses (those that are neither urban nor industrial and that are suitable for agricultural, forestry and livestock-raising activities as defined in [62]).

PAHs can be natural or anthropogenic. Natural sources comprise incomplete natural combustion of carbon-containing fuel such as coal or wood (wildfires), or even volcanic eruptions and petroleum input in oil seeps [76]. On the other hand, energy production, industrial emissions, waste incineration, car exhausts, and biomass burning are common examples of anthropogenic sources [15, 74]. Another remarkable source of PAHs is coal mining since this activity involves the massive use of this fossil fuel for energy production in power stations and also coal waste accumulation and coal processing, which have also led to soil pollution by PAHs around the world [29, 30, 52].

Sources of PAHs can be studied using specific molecular ratios $[33,73]$. In addition, multivariate statistical methods, such as hierarchical cluster analysis (HCA) and principal component analysis (PCA), can unravel relationships between inorganic and organic pollutants [47, 70]. Finally, geostatistical methods (e.g. kriging, inverse-distance weighting (IDW)) allow the characterization and evaluation of the geographical distribution of pollutants $[8,28,40]$.

The municipality of Langreo (Asturias, NW Spain) is an area characterised by heavily industrialized mining activity. In this regard, multiple types of industries-some still in operation and others closed or abandoned-have released pollutants into the environment. By the mid XIX century, these industries had taken up coal mining as a primary activity. Since then, metallurgy, coal power stations, and chemical and fertilizer industries, among others, have successively occupied the main valley in the area [59]. Nowadays, the continuous transition towards cleaner energies and other technologies has impacted this area and many other similar regions in Europe [37], which have all experienced progressive abandonment that started with mine closures. In this context, the European Commission has recently drawn up a list of 14 Coal Regions in Transition, which includes Langreo. Along the same lines, in 2017, the European Commission launched a platform to encourage environmental studies of these areas, among other actions [3].

Potential soil pollution in the area of Langreo and also in specific brownfields has been previously addressed at various scales $[9,10,22]$. It has been concluded that soils of the zone present significant 
pollution by Potentially Toxic Elements (PTEs), in particular As, $\mathrm{Cu}, \mathrm{Hg}, \mathrm{Pb}$ and $\mathrm{Zn}$ in Langreo itself [9] and the neighbouring area [26]. In this context, the simultaneous presence of PAHs and PTEs is foreseeable since both types of pollutant can be released by the same sources, as is the case of coal power stations releasing $\mathrm{Cd}, \mathrm{Cr}, \mathrm{Pb}, \mathrm{Tl}$, or $\mathrm{V}$ together with $\mathrm{BaP}$ and other $\mathrm{PAHs}[38,61]$. In this regard, soils, particularly in urban-peri-urban environments, can provide a geological record of multi point-source pollution $[13,75$, 77].

Given the preceding considerations, this study had the following objectives: 1 ) to examine the presence of $\mathrm{BaP}$ and another 15 (EPA) priority PAHs in the soils of the municipality of Langreo $\left(82 \mathrm{~km}^{2}\right)$, located in the heart of a Coal Region in Transition; 2) to evaluate the validity of Spanish RBSSLs for BaP in the context of regions highly linked to coal mining and heavy industries; and 3) to ascertain whether there is a link between the PAH and PTE pollution observed in Langreo in previous studies. To this end, the study applied a methodology combining multivariate statistical and geostatistical approaches with molecular ratios. We propose that the strategy used herein can be easily extrapolated to studies of similar characteristics.

\section{Methods}

\section{Study area and sampling strategy}

The municipality of Langreo (Asturias, NW Spain, Fig. 1) is a traditional mining and industrial area whose origins date back to 1850 . The most predominant activities have been coal mining, ferrous metallurgy, coal power stations and chemical industries [42]. This long and extensive activity has impacted environmental compartments, as evidenced in previous studies, e.g. PTEs in urban air [46], soils [10] and groundwater [7], and the presence of a number of abandoned brownfields in the area [22].

In the context of geomorphology, the Nalón river crosses this $82 \mathrm{~km}^{2}$ municipality, which is comprised of a series of valleys with altitudes ranging from 200 to $900 \mathrm{~m}$. Our sampling consisted of a representative set of data collected from grasslands, forests, and natural soils in rural and peri-urban areas. The sampling design followed a stratified systematic strategy, covering 10 equidistant transects $(250 \mathrm{~m}$ wide and $1000 \mathrm{~m}$ apart) perpendicular to the Nalón river [9]. This specific direction was chosen to achieve representativeness of the hydrological sub-basins, which in this case are perpendicular to the river. Under this premise, 150 samples were gathered, with the number of samples per transect determined proportionally to its length, the location of sampling within the transects being random (Fig. 1).

Samples were taken from the first $20-25 \mathrm{~cm}$ of soil in each vertex of a 1-m square and its central point. After this, composite samples were passed through a 2-cm mesh screen to remove large material such as organic matter, rocks and gravel. They were then transported to laboratory, stored at $4^{\circ} \mathrm{C}$ to prevent biodegradation, and air-dried at room temperature to prevent evaporation.

\section{Analytical procedures}


Representative soil subsamples weighing $10 \mathrm{~g}$ were extracted with dichloromethane:acetone (1:1) in a Soxtherm system (Gerhardt). Concentrations of PAHs were then determined after sample injection into a 7890A GC System coupled to a 5975C Inert XL MSD with a Triple-Axis Detector (Agilent Technologies), following Environmental Protection Agency (EPA) method 8272 with modifications. A capillary column DB-5 ms (5\% phenyl and 95\% dimethylpolysiloxane) $30 \mathrm{~m} \times 0.25 \mathrm{~mm}$ i.d. $\times 0.25 \mu \mathrm{m}$ film (Agilent Technologies) was used, with He as carrier gas at a flow rate of $1 \mathrm{ml} \cdot \mathrm{min}^{-1}$. The initial oven temperature was $70^{\circ} \mathrm{C}$ (held for $2 \mathrm{~min}$ ), and it was ramped up at $20^{\circ} \mathrm{C} / \mathrm{min}$ to $220^{\circ} \mathrm{C}$, raised to $270^{\circ} \mathrm{C}$ at $10^{\circ} \mathrm{C} / \mathrm{min}$ (held for $1 \mathrm{~min}$ ), then raised to $290^{\circ} \mathrm{C}$ at $10^{\circ} \mathrm{C} / \mathrm{min}$ (held for $1 \mathrm{~min}$ ), and finally ramped up at $10^{\circ} \mathrm{C} / \mathrm{min}$ to $300^{\circ} \mathrm{C}$ (held for $7 \mathrm{~min}$ ). The gas chromatography (GC) injector was operated in splitless mode for $2 \mathrm{~min}$, and its temperature was maintained at $260^{\circ} \mathrm{C}$. The mass spectrometer was operated in selected ion monitoring mode (SIM), and the quantification $\mathrm{m} / \mathrm{z}$ relations were as follows: 128 (Naphthalene, abbreviated N); 152, 153 and 154 (Acenaphthylene, Acy; and Acenaphthene, Ace); 165 and 166 (Fluorene, F); 178 (Phenanthrene, Phe; and Anthracene, Ant); 202 (Fluoranthene, Fluo; and Pyrene, Pyr); 228 (Benz[a]anthracene, BaA; and Chrysene, Chr); 252 (Benzo[b]fluoranthene, BbF; Benzo[k]fluoranthene, BkF; and Benzo[a]pyrene, BaP); and 276 and 278 (Dibenz[a,h]anthracene, DbA; Benzo[ghi]perylene, BghiP; and Indene[1,2,3-cd]pyrene, Ind). The mass spectrometer was operated in electron ionization mode (EI) at $70 \mathrm{eV}$ and was calibrated daily by auto-tuning with perfluorotributylamine (PFTBA). In addition, a qualitative full-scan analysis with a mass range acquisition from 45 to $500(\mathrm{~m} / \mathrm{z})$ was also performed in relevant samples (see results).

In addition, the PTE content of the 150 samples was taken from a geochemical database reported in a previous study [9]. In brief, measurements were carried out by Inductively Coupled Plasma Mass Spectroscopy (ICP-MS) after 1:1:1 "aqua regia" digestion (ISO 9002-accredited Bureau Veritas Laboratories, Vancouver, Canada). The elements analysed and detection limits were: As (0.1 ppm); Ba (0.5 ppm); Cd (0.01 ppm); Co (0.1 ppm); Cr (0.5 ppm) Cu (0.01 ppm); Hg (5 ppb); Mo (0.01 ppm); Ni (0.1 ppm); Pb (0.01 ppm); Sb (0.02 ppm); Tl (0.02 ppm); V (2 ppm); and Zn (0.1 ppm).

\section{Outlier identification and clustering}

Correct application of the multi-variate statistics requires previous detection of extreme values representing anomalous data. Therefore, outliers were identified by means of the percentile 95 of the robust Mahalanobis distance, which is an accepted method to identify anomalous data [44]. The general expression is defined by Eq. (1) as

$$
d(\text { Mahalanobis })=\left[\left(X_{b}-X_{a}\right)^{T} \cdot C^{-1} \cdot\left(X_{b}-X_{a}\right)\right]^{0.5}
$$

where $\mathrm{Xa}$ and $\mathrm{Xb}$ are the pair of objects and $\mathrm{C}$ is the sample covariance matrix. All samples identified as outliers through this equation were included in Cluster 1 (see below).

The remaining samples were grouped in terms of a HCA (Hierarchical Clustering Analysis) that was carried out using SPSS v. 24 software by means of the Ward algorithm and Euclidean distance [50]. 


\section{Molecular ratios}

PAHs were divided into two main groups of compounds on the basis of the number of aromatic rings; low molecular weight PAHs (LMW PAHs, 2-3 aromatic rings) and high molecular weight PAHs (HMW PAHs, 4 or more aromatic rings). HMW PAHs are produced mainly by pyrogenic processes while LMW PAHs have both petrogenic and pyrolytic sources. Thus, a concentration ratio of HMW/LMW $>1$ may reflect the pyrogenic nature of PAHs [71]. In subsequent steps, a large number of molecular ratios can be calculated conceived, and some such ratios were used in this study to propose sources (Table 1).

Table 1. List of typical PAH ratios and molecular indices used in this study for source diagnosis, together with their typical reported values.

\begin{tabular}{|c|c|c|c|}
\hline Ratio & Range/value & Source & Reference \\
\hline \multirow[t]{2}{*}{$\Sigma$ HMW/ $\Sigma$ LMW } & $>1$ & Pyrogenic & \multirow[t]{2}{*}[80]{} \\
\hline & $<1$ & Petrogenic & \\
\hline \multirow[t]{3}{*}{ Fluo/(Fluo+Pyr) } & $<0.4$ & Petrogenic & \multirow[t]{3}{*}{ [17] } \\
\hline & $0.4-0.5$ & Fuel combustion & \\
\hline & $>0.5$ & Grass, wood and coal combustion & \\
\hline \multirow[t]{3}{*}{ Ind/(Ind + BghiP) } & $<0.2$ & Petrogenic & \multirow[t]{3}{*}{ [79] } \\
\hline & $0.2-0.5$ & Fuel combustion & \\
\hline & $>0.5$ & Grass, wood and coal combustion & \\
\hline \multirow[t]{2}{*}{$\mathrm{A} /(\mathrm{A}+\mathrm{Phe})$} & $<0.1$ & Petrogenic & \multirow[t]{2}{*}[58]{} \\
\hline & $>0.1$ & Pyrogenic & \\
\hline
\end{tabular}

As seen above, ratios such as Fluo/(Fluo + Pyr) and Ind/(Ind + BghiP) provide a larger discrimination within pyrogenic sources, whereas others such as $A /(A+P h e)$ are applied specifically to differentiate between petrogenic and pyrogenic sources.

\section{Spatial distribution of Benzo[a]pyrene}

The spatial distribution of a variable can be determined through geostatistical techniques. Of these, Ordinary Kriging (OK) is a widely accepted interpolation approach used in environmental studies when data present a Gaussian distribution. In this regard, the performance of an interpolation by OK requires the design of a variogram, that is used to calculate the spatial variation structure of regionalized variables [27, 31]. It is defined as follows (Eq. 2)

$$
\gamma(h)=\frac{1}{2 N(h)} \sum_{i=1}^{N(h)}\left[Z\left(x_{i}\right)-Z\left(x_{i}+h\right)\right]^{2}
$$

where $h$ is the distance argument, and $Z(X i)$ and $Z(X i+h)$ are numerical values of a variable observed at point $\mathrm{Xi}$ and $\mathrm{Xi}+\mathrm{h} . \mathrm{N}(\mathrm{h})$ is the number of pairs forming for an $\mathrm{h}$ distance. Therefore, it is the median value 
of the square of the distances between all pairs of points in the geometric field spaced at an $\mathrm{h}$ distance [43].

In this study, OK was used to determine the spatial distribution of $\mathrm{BaP}$ in the soils of Langreo. Given the known presence of outliers, normality conditions could not be achieved with raw data and thus a logtransformation was used. The geostatistical simulation was done using Biomedware's SpaceStat v. 4.0 software.

\section{Correlation Benzo[a]pyrene - PTEs}

The degree of relationship between BaP and PTEs was studied by factor analysis. The number of factors was determined by the Kaiser/Guttman criterion while the principal components method was used for factor extraction, following recommendations for geochemical data $[21,63]$. These calculations were made using SPSS v. 24.

\section{Results And Discussion}

\section{PAH content in the study area}

The eescriptive statistics for PAH concentrations of the 150 soil samples in Langreo are shown in Table 2. At first glance, a notable variability in the concentrations of all the compounds can be appreciated. This observation implies marked heterogeneity in these soils in terms of PAH content, especially those with four or more rings (HMW PAHs), as suggested by many high RSD values, which are concordant with the differences between the mean and the median. On the whole, data did not show normality, thus evidencing the presence of outliers.

In turn, our results also revealed the predominance of HMW PAHs. If we apply the most restrictive Spanish RBSSLs, namely "other uses" (in fact this category accounts for more than $90 \%$ of the soils where the samples were taken), around $5-15 \%$ of samples exceeded the threshold levels for heavy PAHs such as $\mathrm{BaA}, \mathrm{BbF}, \mathrm{DbA}$ and Ind. Of note, BaP surpassed the legal limits in $79 \%$ of the samples, presenting a median that was almost 20 times the value of the RBSSL.

Table 2. Statistical summary of the analysis PAHs in the 150 samples. Range, Mean and Median and relative standard deviation (RSD). The RSD after outlier removal (RSD*, see above) and the most restrictive RBSSL are also provided. All units are expressed in mg.kg-1 ${ }^{-1}$ except RSD and RSD*, which are expressed as a \%. 


\begin{tabular}{c|cccccccc} 
PAH & Rings & RBSSL & Range & Mean & Median & RSD & RSD* & No. Samples surpassing RBSSL \\
\hline N & 2 & 1 & $0.01-0.74$ & 0.06 & 0.02 & 182 & 172 & 0 \\
Acy & 3 & - & $0.01-0.36$ & 0.03 & 0.01 & 190 & 111 & - \\
Ace & 3 & 6 & $0.01-3.1$ & 0.04 & 0.01 & 710 & 52 & 0 \\
F & 3 & 5 & $0.01-2.6$ & 0.03 & 0.01 & 612 & 80 & - \\
Phe & 3 & - & $0.012-70$ & 0.64 & 0.06 & 898 & 123 & 0 \\
A & 3 & 45 & $0.01-13$ & 0.13 & 0.01 & 836 & 115 & - \\
\hline LMW & - & - & $0.062-89.4$ & 0.92 & 0.13 & 795 & 110 & $1(0.7 \%)$ \\
\hline Fluo & 4 & 8 & $0.01-140$ & 1.18 & 0.09 & 970 & 125 & $17(11 \%)$ \\
Pyr & 4 & 6 & $0.01-120$ & 1.00 & 0.07 & 982 & 124 & $1(0.7 \%)$ \\
BaA & 4 & 0,2 & $0.01-50$ & 0.44 & 0.04 & 928 & 121 & $33(22 \%)$ \\
Chr & 4 & 20 & $0.01-48$ & 0.45 & 0.06 & 868 & 115 & $1(0.7 \%)$ \\
BbF & 5 & 0.2 & $0.01-68$ & 0.64 & 0.07 & 874 & 123 & $119(79 \%)$ \\
BkF & 5 & 2 & $0.01-21$ & 0.20 & 0.02 & 847 & 123 & $17(11 \%)$ \\
BaP & 5 & 0.02 & $0.01-42$ & 0.38 & 0.04 & 895 & 129 & - \\
DbA & 5 & 0.03 & $0.01-5.7$ & 0.06 & 0.01 & 778 & 93 & - \\
BghiP & 6 & - & $0.01-35$ & 0.32 & 0.04 & 893 & 118 & $(5 \%)$ \\
Ind & 6 & 0.3 & $0.01-2.3$ & 0.09 & 0.04 & 239 & 124 & - \\
\hline$\Sigma$ HMW & - & - & $0.1-530$ & 4.75 & 0.46 & 910 & 120 & 111 \\
\hline$\Sigma$ PAH & - & - & $0.163-619$ & 5.67 & 0.62 & 891 & 17 \\
\hline
\end{tabular}

\section{Outliers and clustering}

The high RSDs suggest the presence of outliers in the data set. To identify these outliers, percentile 95 of the Robust Mahalanobis distance was used. The results are shown in Fig. 2. Seven samples were identified as outliers and separated into an independent group (namely Cluster 1). Once outliers had been identified, the statistical analysis was repeated with the remaining 143 samples. An improvement in normality was observed, mainly through the reduction of the RSD coefficient (see RSD*, in Table 2).

The exclusion of outliers is also useful to reduce uncertainty and noise, thereby enhancing group formation in the HCA. In this context, the dendrogram resulting from this multivariate analysis of PAHs in the 143 soil samples was mapped as shown in Fig. 3, together with the mean content of LMW, HMW PAHs and also BaP. Three clusters (four after manual addition of Cluster 1 - Outliers) were found.

- Cluster 1: Corresponding to the 7 outliers previously identified. The concentrations of LMW and HMW PAHs were very high in these samples with regard to the other groups, and therefore mean values should be interpreted with care due to the presence of extreme values.

- Cluster 2: This was the group with the lowest number of samples (5), all of them located in the urban/peri-urban area of Langreo. These samples presented a notable concentration of HMW PAHs. Given the size of the group and values, this group could be considered an extension of Cluster 1. 
- Cluster 3: This group (35 samples) comprised soils with a moderate concentration of HMW PAHs. The samples were generally located halfway between peri-urban and rural areas, further away from urban cores or heavy industries than Clusters 1 and 2.

- Cluster 4: This group (103 samples) was the most numerous and included samples with lower PAH concentrations than the previous clusters. It showed the same pattern of decreasing concentrations with increasing distance from the urban-industrial core (Fig. 3). Note that this cluster contained samples that did not surpass the RBSSL for BaP and also some that surpassed this value slightly. Consequently, this group corresponded to soils with a lower degree of contamination.

On the whole, the concentration of PAHs in the soil increased dramatically with proximity to the urban and industrial core (Fig. 3). The pollution was, therefore, located mainly in areas that held the the largest number of sources.

\section{PAH sources}

Of note, the distribution of individual PAHs revealed a relatively homogeneous fingerprint for the four clusters (predominance of 3-4-ring compounds such as Phenanthrene, Fluoroanthene and Pyrene), thereby suggesting similar profiles and common sources (Fig. 4), with the possible exception of Cluster 1.

Regarding the molecular diagnostic ratios, the mean concentration ratio of $\Sigma \mathrm{HMW} / \Sigma \mathrm{LMW}$ was higher than 1 for all the clusters, initially suggesting that the PAH source was pyrogenic (Table 3)[80]. Furthermore, the $\mathrm{A} /(\mathrm{A}+\mathrm{Phe})$ ratio reaffirmed the pyrogenic hypothesis, as values higher than 0.1 were found [58]. The values found for the Ind/(Ind + BghiP) and Fluo/(Fluo + Pyr) ratios suggest grass, wood and coal combustion $[17,79]$. According to these data and the industrial profile of the area, coal burning activities (power station, metallurgical activities, chemical industry, etc.) are most likely to be the main source of PAHs. However, emission from the coal-fuelled heating systems in houses cannot be ruled out as these systems were used for decades (still active in many locations) both in rural and urban areas.

Table 3. Molecular diagnostic ratios for mean concentrations of PAHs for each cluster.

\begin{tabular}{ccccc}
\hline Cluster & $\Sigma$ HMW/ $\Sigma$ LMW & A/(A+Phe) & Ind/(Ind+BghiP) & Fluo/(Fluo+Pyr) \\
\hline 1 & 5.72 & 0.17 & 0.50 & 0.54 \\
\hline 2 & 5.95 & 0.23 & 0.50 & 0.55 \\
3 & 3.14 & 0.15 & 0.50 & 0.55 \\
\hline 4 & 3.20 & 0.19 & 0.50 & 0.55 \\
\hline
\end{tabular}

Nevertheless, it should be noted that these and other ratios have several limitations [71]. In fact, relative proportions of the organic compounds are usually assumed to be conserved between each emission source and the downwind measurement point [65], and they do not take into account possible alterations of the target compounds in soil (biodegradation, etc.). This implies that the diagnostic ratio results 
should preferably be used as a guiding methodology to reinforce a hypothesis and not as a conclusive tool. In this context, here we applied the molecular diagnostic ratios combined with complementary interpretation methods, such as the cluster analysis and the factor analysis (see below).

On the other hand, the previous statement (diffuse pollution caused by pyrogenic PAH sources) could be masking the additional existence of potential point-sources. In this context, although the identification of local point sources (associated with brownfields, spills, waste disposal, etc.) was beyond the objectives of this work, the two main outliers found (samples 76 and 29 as shown in Fig. 2) were analysed in-depth to exemplify the superposition of diffuse and point source effect., this was done using a qualitative GCMS approach. As shown in Fig. 5a, the chromatographic fingerprint of sample 76 differed greatly to that of 29. Indeed, the former reflects the fingerprint of a coal tar distillate [19] while the latter shows a typical profile of an oil derivative [36]. However, at the same time, the star diagram revealed a very similar PAH fingerprint profile for both samples (Fig. 5a). For sample 76, additional information from specific compounds such as alkanes (Fig. $5 \mathrm{~b}$ ) revealed the abundance of odd carbon number n-alkanes, typical of terrestrial vegetation [57; 72], whereas the alkane fingerprint of sample 29 showed the abundance of light-medium $n$-alkanes and isoprenoids, as corresponds to petroleum products [57]. Finally, detailed insight into a representative PAH (phenanthrene, see Fig. 5c) showed a clear predominance of the parentPAH in sample 76, thereby pointing to the coal tar hypothesis [67]. In contrast, the PAH alkyl-derivatives in sample 29 were much more abundant, suggesting a mixture of both pyrogenic and petrogenic inputs [79].

\section{Benzo[a]pyrene: A real anomaly in the study area?}

A geostatistical analysis of BaP content was carried out to determine its distribution across the study area. OK was applied after performing a log-transformation of the 150 data set of $\mathrm{BaP}$ analyses in order to improve normality conditions, which are mandatory in kriging. The resulting map is shown in Fig. 6a. As with PAHs, the concentration of $\mathrm{BaP}$ in soils was higher in the urban and peri-urban area than in the rural environments. In addition, the predicted content consistently surpassed the RBSSL $\left(0.02 \mathrm{mg} \cdot \mathrm{kg}^{-1}\right)$. This observation reflects the high degree of pollution present in the soils. In this respect, from the regulatory perspective, practically any site within the entire municipality would require site-specific risk assessment to determine contamination by BaP. Consequently, it is questionable whether the official RBSSLs in Spain are useful in areas with a long history of industrial activity, particularly in Coal Regions in Transition.

Moreover, as seen in the map, BaP enrichment in soils presents a trend towards the full range of NW/SE directions (see 3D images in Fig. 6b). According to data from MERRA-2 (Modern-Era Retrospective Analysis from NASA, see [24], wind direction in Langreo is preferentially westerly from mid-February to the end of April; northerly, from May to mid-September; and southerly from mid-September to mid-February, while easterly winds are never predominant in this area. These wind patterns are consistent with the abovementioned spatial distribution of $\mathrm{BaP}$-which is also conditioned by the topography-thereby 
strongly supporting the notion that PAH diffusion occurs by atmospheric deposition through the main valley.

Given the preceding considerations, we conclude that the soil background of the municipality of Langreo present a high enrichment in $\mathrm{BaP}$. An indicative value can be calculated by the method previously used in [10 and references therein] for trace elements in Langreo. In brief, and once excluding the samples in Cluster 1 (outliers), the geochemical background (threshold) can be calculated in a straightforward manner through the mean $\mathrm{BaP}$ concentration plus two times the standard deviation of the data set. Following this procedure, the resulting background concentration was $0.24 \mathrm{mg} \cdot \mathrm{kg}^{-1}$, more than ten times the RBSSL for "other uses" of soil $\left(0.02 \mathrm{mg} \cdot \mathrm{kg}^{-1}\right)$, and even above the RBSSL for urban uses $\left(0.2 \mathrm{mg} \cdot \mathrm{kg}^{-}\right.$ $\left.{ }^{1}\right)$. The background obtained was in the same range as other locations with BaP-enriched soil, such as the areas of Abadan, Iran (0.061 $\left.\mathrm{mg} \cdot \mathrm{kg}^{-1}\right)$ [25], Sydney, Australia $\left(0.22 \mathrm{mg} \cdot \mathrm{kg}^{-1}\right)$ [54], Delmarva, USA $\left(0.39 \mathrm{mg} \cdot \mathrm{kg}^{-1}\right)$ [35], Berre, France $\left(0.26 \mathrm{mg} \cdot \mathrm{kg}^{-1}\right)$ [4], Mecoacán, Mexico $\left(0.22 \mathrm{mg} \cdot \mathrm{kg}^{-1}\right)$ [5], and Torino, Italy $\left(0.23 \mathrm{mg} \cdot \mathrm{kg}^{-1}\right)[49]$.

In conclusion, the soils of Langreo, an area with a long history of industrial activity, present a geochemical background that is highly enriched in BaP, surpassing the Spanish RBSSL. This finding can be explained by the fact that the RBSSLs for PAHs are based on toxicological values and do not consider historical backgrounds. The legislation of other countries has less restrictive limits for $\mathrm{BaP}$ in soils (Table 4). However, the background of Langreo would even surpass many of these limits. The wide range of toxicological data and methodologies used to establish such limits do not consider the effects of historical diffuse pollution. Consequently, these levels do not have the precision needed to evaluate BaP pollution in heavily industrialized areas, such as the one presented here or other sites with similar characteristics worldwide.

Table 4. Comparison of the Langreo background and RBSSLs in Spain and other countries.

\begin{tabular}{cccc} 
Location & BaP mg.kg & Restriction & Reference \\
\hline Langreo background & 0.24 & - & This study \\
\hline Spain & $0.02 / 0.2$ & Other / residential use of soil & {$[62]$} \\
\hline United Kingdom & 0.15 & Land recovery threshold & {$[41]$} \\
\hline Czech Republic & 0.1 & General soil screening value for negligible risk & {$[69]$} \\
\hline Netherlands & 0.26 & Maximum permissible concentration in soils & {$[32]$} \\
\hline Slovakia & 0.1 & General soil screening value for negligible risk & {$[69]$} \\
\hline Denmark & 0.1 & Very sensitive land use & {$[16]$} \\
\hline New Zealand & 0.27 & Residential soil use (surface $<1 \mathrm{~m})$ & {$[48]$} \\
\hline
\end{tabular}

\section{BaP correlation with PTE anomalies}


A previous study reported the presence of PTE anomalies in the soil of Langreo [9]. Therefore, there may be a relationship between pollution by PTEs and PAHs, since the industrial processes described in previous sections facilitate the co-occurrence of both inorganic and organic contaminant emission. To this end, we carried out factor analyses, considering the multivariate database, including PTEs [9], together with the new BaP data. In order to identify different trends, we applied two approaches with enough samples to offer statistical significance. The first used the 47 samples from Clusters 1, 2 and 3 (corresponding to the soil with the highest PAH concentrations, as shown above), while the second used the 103 samples of Cluster 4, with the lowest concentrations. The results are shown in Table 5.

For the first case, the value of the Kaiser-Meyer-Olkin test for the factor analysis was a significant 0.782 , providing reliable results. Three factors explained more that $80 \%$ of the total variance:

- The first factor comprised $\mathrm{Cu}, \mathrm{Pb}, \mathrm{Cd}, \mathrm{Sb}, \mathrm{Zn}, \mathrm{Ba}$ and $\mathrm{Cr}$, a typical association of heavy metals that contains some of the main pollutants of the area [9]. BaP showed a null relationship with this group, suggesting that the sources differed. In this regard, previous studies reported the presence of some of these potential pollutants linked to the heavy industry (metallurgy mainly) and traffic, especially $\mathrm{Pb}[39,60]$.

- The second factor included high loads for $\mathrm{V}, \mathrm{As}, \mathrm{Tl}$, and secondarily for $\mathrm{Mo}$ and $\mathrm{Fe}$, together with the highest load of $\mathrm{BaP}(0.631)$. $\mathrm{V}$ and $\mathrm{Tl}$ are frequently associated with coal emissions [12, 38], and in Langreo they have been previously linked to coal combustion and are therefore detected in $\mathrm{PM}_{10}$ particles [53]. Moreover, As has also been identified as a common pollutant in activities involving coal burning [34]. This association with typical trace elements of coal emission supports the hypothesis of the sources of PAHs presented above. However, BaP presented a low communality (0.415), which suggests that it shows a distinct behaviour to that of these elements.

- Co, Mn, Ni and Mg were included mainly in a third group. This association probably corresponds to geogenic elements present in background concentrations in the area.

The results for the "low pollution" Cluster $4(\mathrm{KMO}=0.702)$ demonstrated BaP loadings (Table 5) divided among three distinct factors without special significance, and no clear relationship with any inorganic element. This finding suggests that the lower extent of pollution in rural areas dilutes the correlation between organic and inorganic emissions.

Table 5. Factor loadings, percentage of variance explained by the Varimax-rotated factors (extracted by principal components) and communalities. Highest loadings for factor are marked in bold. Pearson's Coefficient with BaP is also included. 


\begin{tabular}{|c|c|c|c|c|c|c|c|c|c|c|}
\hline & \multicolumn{4}{|c|}{ Cluster $1+2+3$ (Higher pollution) } & & \multicolumn{4}{|c|}{ Cluster 4 (Lower pollution) } & \multirow[b]{2}{*}{ Com. } \\
\hline & F1 & F2 & F3 & Com. & & F1 & F2 & F3 & F4 & \\
\hline $\mathrm{Cd}$ & 0.982 & 0.086 & 0.126 & 0.988 & Co & 0.910 & 0.044 & -0.003 & 0.015 & 0.831 \\
\hline $\mathrm{Sb}$ & 0.981 & 0.086 & 0.110 & 0.982 & $\mathrm{Ni}$ & 0.852 & 0.137 & 0.087 & -0.167 & 0.823 \\
\hline $\mathrm{Cu}$ & 0.980 & 0.090 & 0.141 & 0.988 & $\mathrm{Mn}$ & 0.744 & 0.076 & -0.013 & -0.050 & 0.562 \\
\hline $\mathrm{Pb}$ & 0.975 & 0.142 & 0.113 & 0.983 & $\mathrm{Cu}$ & 0.680 & 0.432 & -0.163 & 0.356 & 0.804 \\
\hline $\mathrm{Zn}$ & 0.956 & 0.168 & 0.193 & 0.979 & $\mathrm{Fe}$ & 0.658 & -0.038 & 0.598 & -0.089 & 0.808 \\
\hline $\mathrm{Ba}$ & 0.870 & 0.147 & 0.292 & 0.863 & $\mathrm{Mg}$ & 0.568 & 0.069 & 0.074 & -0.426 & 0.665 \\
\hline $\mathrm{Cr}$ & 0.740 & 0.289 & 0.366 & 0.765 & $\mathrm{~Pb}$ & -0.020 & 0.904 & 0.042 & 0.096 & 0.828 \\
\hline $\mathrm{V}$ & 0.061 & 0.849 & -0.191 & 0.761 & $\mathrm{Ba}$ & 0.224 & 0.853 & 0.027 & -0.097 & 0.788 \\
\hline As & 0.357 & 0.778 & 0.060 & 0.737 & $\mathrm{Zn}$ & 0.445 & 0.767 & 0.147 & 0.148 & 0.841 \\
\hline $\mathrm{Tl}$ & 0.177 & 0.748 & -0.272 & 0.664 & $\mathrm{BaP}$ & -0.092 & 0.377 & 0.323 & 0.274 & 0.340 \\
\hline Mo & 0.586 & 0.693 & -0.009 & 0.824 & V & -0.023 & -0.065 & 0.794 & 0.417 & 0.826 \\
\hline $\mathrm{Fe}$ & 0.235 & 0.677 & 0.530 & 0.794 & $\mathrm{Cr}$ & 0.420 & 0.321 & 0.728 & -0.200 & 0.860 \\
\hline $\mathrm{BaP}$ & -0.080 & 0.631 & 0.105 & 0.415 & $\mathrm{Tl}$ & -0.264 & 0.142 & 0.567 & 0.129 & 0.600 \\
\hline Co & 0.278 & -0.062 & 0.903 & 0.896 & As & -0.076 & -0.066 & 0.188 & 0.792 & 0.674 \\
\hline Mn & -0.005 & 0.118 & 0.820 & 0.686 & $\mathrm{Sb}$ & -0.063 & 0.495 & -0.250 & 0.663 & 0.813 \\
\hline $\mathrm{Ni}$ & 0.430 & 0.014 & 0.816 & 0.851 & Mo & 0.037 & 0.470 & 0.272 & 0.586 & 0.639 \\
\hline $\mathrm{Mg}$ & 0.178 & -0.311 & 0.770 & 0.721 & $\mathrm{Cd}$ & 0.181 & -0.014 & -0.018 & 0.032 & 0.763 \\
\hline Cumul. expl. var. (\%) & 49.575 & 69.299 & 81.759 & & Cumul. expl. var. (\%) & 29.143 & 47.706 & 59.365 & 66.793 & \\
\hline
\end{tabular}

\section{Conclusions}

Here we conducted a high-density soil sampling and analysis (150 samples) in one of the historically most industrialized areas of Spain. Our results revealed high HMW PAH concentrations for BaA, BbF, DbA, Ind, and a particularly anomalous content of BaP.

Multivariate statistics were used to group samples within the study area after the identification of outliers via the Mahalanobis distance. We conclude that clustering is influenced mainly by the total concentration of PAHs, which is lower in soils of the rural or mountainous areas than in the urban and peri-urban zones. Most of the anomalous PAH contents were attributed to atmospheric deposition of pyrogenic particles originated in coal combustion processes, as revealed by molecular diagnostic ratios (diffuse pollution). However, some of the outliers found had local point-source origins, which should be addressed in further studies given the very high concentrations detected. The location of the main industries and the urban core, the predominant winds, and the topography of the area emerge as key factors in the distribution of the pollutants. Also, BaP showed a partial but significant correlation with PTEs commonly associated with coal combustion, such as V, TI and As. This observation thus supports the hypothesis of pollution by atmospheric deposition.

Regarding the $\mathrm{BaP}$ anomaly, our geostatistical study confirmed that its concentration greatly exceeds the RBSSLs in the entire study area. In this context, a geochemical background of $0.24 \mathrm{mg} \cdot \mathrm{kg}^{-1}$ was found, 
surpassing the Spanish RBSSLs currently in force (based on only toxicity features and soil use). Consequently, this study questions the usefulness of RBSSLs as a valid reference for areas with a high density of heavy industries (past and present), particularly those linked to coal. This consideration should be taken into account when developing environmental policies for Coal Regions in Transition.

Here we conducted a high-density soil sampling and analysis (150 samples) in one of the historically most industrialized areas of Spain. Our results revealed high HMW PAH concentrations for BaA, BbF, DbA, Ind, and a particularly anomalous content of BaP.

Multivariate statistics were used to group samples within the study area after the identification of outliers via the Mahalanobis distance. We conclude that clustering is influenced mainly by the total concentration of PAHs, which is lower in soils of the rural or mountainous areas than in the urban and peri-urban zones. Most of the anomalous PAH contents were attributed to atmospheric deposition of pyrogenic particles originated in coal combustion processes, as revealed by molecular diagnostic ratios (diffuse pollution). However, some of the outliers found had local point-source origins, which should be addressed in further studies given the very high concentrations detected. The location of the main industries and the urban core, the predominant winds, and the topography of the area emerge as key factors in the distribution of the pollutants. Also, BaP showed a partial but significant correlation with PTEs commonly associated with coal combustion, such as $\mathrm{V}, \mathrm{Tl}$ and As. This observation thus supports the hypothesis of pollution by atmospheric deposition.

Regarding the BaP anomaly, our geostatistical study confirmed that its concentration greatly exceeds the RBSSLs in the entire study area. In this context, a geochemical background of $0.24 \mathrm{mg} \cdot \mathrm{kg}^{-1}$ was found, surpassing the Spanish RBSSLs currently in force (based on only toxicity features and soil use). Consequently, this study questions the usefulness of RBSSLs as a valid reference for areas with a high density of heavy industries (past and present), particularly those linked to coal. This consideration should be taken into account when developing environmental policies for Coal Regions in Transition.

\section{Abbreviations}

Ace: acenaphthene; Acy: acenaphthylene; Ant: anthracene; BaA: benz[a]anthracene; BaP: benzo[a]pyrene; BbF: benzo[b]fluoranthene; BghiP: benzo[ghi]perylene; BkF: benzo[k]fluoranthene; Chr: chrysene; DbA: dibenz[a,h]anthracene; EC: European Comission; El: electron ionization; EPA: Environmental Protection Agency; EU: European Union; F: fluorene; Fluo: fluoranthene; GC: gas chromatography; HCA: hierarchical cluster analysis; HMW: high molecular weight; ICP-MS: inductively coupled plasma mass spectrometry; IDW: inverse-distance weighing; Ind: indeno[1,2,3-cd]pyrene; INDUROT: Institute of Natural Resources and Territorial Planning (University of Oviedo); kg: kilogram; LMW: low molecular weight; mg: milligram; $\mathbf{N}$ : naphthalene; NASA: National Aeronautics and Space Administration; NW: Northwest; OK: Ordinary Kriging; PAH: Polycyclic Aromatic Hydrocarbon; PCA: principal component analysis; PFTBA: perfluorotributylamine; Phe: phenanthrene; PTE: Potentially Toxic Element; Pyr. pyrene; RBSSL: Risk- 
Based Soil Screening Level; RD: Real Decreto (A decree made by the Spanish Government); RSD: relative standard deviation; SE: Southeast; SIM: selected ion monitoring

\section{Declarations}

\section{Acknowledgements}

D. Baragaño obtained a "Formación del Profesorado Universitario" grant from the Ministerio de Educación y Formación Profesional of the Spanish Government.

\section{Authors' contributions}

C. Boente and D. Baragaño were responsible for the sampling campaign, and preparation and analysis of samples. C. Boente led the writing and composition of tables/figures and structured the article. D. Baragaño provided support for the writing and a second opinion regarding the discussion and conclusions. J.R. Gallego coordinated the work, participated in the design of the experimental section, the interpretation and discussion of results, and supervised the manuscript.

\section{Funding}

The project has been self-funded.

\section{Availability of data and materials}

The dataset used and/or analysed in this study is available from the corresponding author upon reasonable request.

\section{Ethics approval and consent to participate}

Not applicable.

\section{Consent for publication}

All authors read and provided their consent for publication.

\section{Competing interests}

The authors declare that they have no competing interests.

\section{Author details}

1 INDUROT and Environmental Technology, Biotechnology and Geochemistry Group, Campus de Mieres, Universidad de Oviedo, 33600, Mieres, Spain

\section{References}


1. Albanese S, Fontaine B, Chen W, Lima A, Cannatelli C, Piccolo A, Qi S, Wang M, De Vivo B (2015) Polycyclic aromatic hydrocarbons in the soils of a densely populated region and associated human health risks: the Campania Plain (Southern Italy) case study. Environ Geochem Health 37:1-20. https://doi.org/10.1007/s10653-014-9626-3

2. Allan SE, Smith BW, Anderson KA (2012) Impact of the Deepwater Horizon Oil Spill on Bioavailable Polycyclic Aromatic Hydrocarbons in Gulf of Mexico Coastal Waters. Environ Sci Technol 46:20332039. https://doi.org/10.1021/es202942q

3. Alves-Dias P, Kanellopoulos K, Medarac H, Kapetaki Z, Miranda-Barbosa E, Shortall R, Czako V, Telsnig T, Vázquez-Hernández C, Lacal-Arantegui R, Nijs W, González-Aparicio I, Trombetti M, Mandras G, Peteves E, Tzimas E (2018) EU coal regions: opportunities and challenges ahead.

4. Arienzo M, Masuccio AA, Ferrara L, (2013) Evaluation of Sediment Contamination by Heavy Metals, Organochlorinated Pesticides, and Polycyclic Aromatic Hydrocarbons in the Berre Coastal Lagoon (Southeast France). Arch Environ Contam Toxicol 65:396-406. https://doi.org/10.1007/s00244-0139915-3

5. Armenta-Arteaga G, Elizalde-González MP (2003) Contamination by PAHs, PCBs, PCPs and heavy metals in the mecoácfin lake estuarine water and sediments after oil spilling. J Soils Sediments 3:35-40. https://doi.org/10.1007/BF02989467

6. Baird WM, Hooven LA, Mahadevan B (2005) Carcinogenic polycyclic aromatic hydrocarbon-DNA adducts and mechanism of action. Environ Mol Mutagen 45:106-114.

https://doi.org/10.1002/em.20095

7. Baragaño D, Boente $C$, Rodríguez-Valdés E, Fernández-Braña A, Jiménez A, Gallego JLR, GonzálezFernández B (2020) Arsenic release from pyrite ash waste over an active hydrogeological system and its effects on water quality. Environ Sci Pollut Res. https://doi.org/10.1007/s11356-019-07120-8

8. Baran A, Wieczorek J, Mazurek R, Urbański K, Klimkowicz-Pawlas A (2018) Potential ecological risk assessment and predicting zinc accumulation in soils. Environ Geochem Health 40:435-450. https://doi.org/10.1007/s10653-017-9924-7

9. Boente C, Albuquerque MTD, Fernández-Braña A, Gerassis S, Sierra C, Gallego JR (2018) Combining raw and compositional data to determine the spatial patterns of Potentially Toxic Elements in soils. Sci Total Environ. 631-632:1117-1126. https://doi.org/10.1016/j.scitotenv.2018.03.048

10. Boente C, Gerassis S, Albuquerque MTD, Taboada J, Gallego JR (2019) Local versus Regional Soil Screening Levels to Identify Potentially Polluted Areas. Math Geosci https://doi.org/10.1007/s11004019-09792-x 
11. Cachada A, Dias A, Reis A, Ferreira da Silva E, Pereira R, Duarte A, Patinha C (2019) Multivariate Analysis for Assessing Sources, and Potential Risks of Polycyclic Aromatic Hydrocarbons in Lisbon Urban Soils. Minerals 9:139. https://doi.org/10.3390/min9030139

12. Chen Y, Wang C, Liu J, Wang J, Qi J, Wu Y (2013) Environmental exposure and flux of thallium by industrial activities utilizing thallium-bearing pyrite. Sci China Earth Sci 56:1502-1509. https://doi.org/10.1007/s11430-013-4621-6

13. Ciarkowska K, Gambus F, Antonkiewicz J, Koliopoulos T (2019) Polycyclic aromatic hydrocarbon and heavy metal contents in the urban soils in southern Poland. Chemosphere 229:214-226. https://doi.org/10.1016/j.chemosphere.2019.04.209

14. Commission Regulation (EC) No 1881/2006 of December 2006 OJ L 364, 2006. p. 5 and Amending Commission Regulation (EC) No 835/2011 of 19 August 2011 L 215/4, 20-08-2011, p. 5.

15. Coxon T, Goldstein L, Odhiambo BK (2019) Analysis of spatial distribution of trace metals, PCB, and PAH and their potential impact on human health in Virginian Counties and independent cities, USA. Environ Geochem Health 41:783-801. https://doi.org/10.1007/s10653-018-0172-2

16. Danish Environmental Protection Agency (2002). Danish PAH soil quality criteria.

17. De La Torre-Roche RJ, Lee WY, Campos-Díaz SI (2009) Soil-borne polycyclic aromatic hydrocarbons in El Paso, Texas: Analysis of a potential problem in the United States/Mexico border region. J Hazard Mater 163:946-958. https://doi.org/10.1016/j.jhazmat.2008.07.089

18. Directive 2004/107/EC of the European Parliament and of the Council of 15 December 2004 relating to arsenic, cadmium, mercury, nickel and polycyclic aromatic hydrocarbons in ambient air. Official Journal of the European Union, 26.1.2005.

19. Emsbo-Mattingly SD, Stout SA (2011) Semivolatile residues of coal and coal tar, in: Stracher, G.B., Prakash, A., Sokol, E.V. (Eds.), Coal and Peat Fires: A Global Perspective. Elsevier, pp 173-208. https://doi.org/10.1016/B978-0-444-52858-2.00011-6

20. Environmental Protection Agency (2012) 40 CFR Part 423, Appendix A.

21. Facchinelli A, Sacchi E, Mallen L (2001) Multivariate statistical and GIS-based approach to identify heavy metal sources in soils. Environ Pollut 114(3):313-324. https://doi.org/10.1016/S02697491(00)00243-8

22. Gallego JR, Rodríguez-Valdés E, Esquinas N, Fernández-Braña A, Afif E (2016) Insights into a 20-ha multi-contaminated brownfield megasite: An environmental forensics approach. Sci Total Environ 563-564:683-692. https://doi.org/10.1016/j.scitotenv.2015.09.153 
23. Gao P, da Silva EB, Townsend T, Liu X, Ma LQ (2019) Emerging PAHs in urban soils: Concentrations, bioaccessibility, and spatial distribution. Sci Total Environ 670:800-805.

https://doi.org/10.1016/j.scitotenv.2019.03.247

24. Gelaro R, McCarty W, Suárez M.J, Todling R, Molod A, Takacs L, Randles CA, Darmenov A, Bosilovich MG, Reichle R, Wargan K, Coy L, Cullather R, Draper C, Akella S, Buchard V, Conaty A, da Silva AM, Gu W, Kim GK, Koster R, Lucchesi R, Merkova D, Nielsen JE, Partyka G, Pawson S, Putman W, Rienecker M, Schubert SD, Sienkiewicz M, Zhao B (2017) The Modern-Era Retrospective Analysis for Research and Applications, Version 2 (MERRA-2). J Clim 30:5419-5454. https://doi.org/10.1175/JCLI-D-160758.1

25. Ghanavati N, Nazarpour A, Watts MJ (2019) Status, source, ecological and health risk assessment of toxic metals and polycyclic aromatic hydrocarbons (PAHs) in street dust of Abadan, Iran. CATENA 177:246-259. https://doi.org/10.1016/j.catena.2019.02.022

26. González-Fernández B, Rodríguez-Valdés E, Boente $C$, Menéndez-Casares E, Fernández-Braña A, Gallego JR (2018) Long-term ongoing impact of arsenic contamination on the environmental compartments of a former mining-metallurgy area. Sci Total Environ 610-611:820-830. https://doi.org/10.1016/j.scitotenv.2017.08.135

27. Gringarten E, Deutsch CV (2001) Teacher's Aide Variogram Interpretation and Modeling. Math Geol 33:507-534. https://doi.org/10.1023/a:1011093014141

28. Guagliardi I, Cicchella D, De Rosa R, Ricca N, Buttafuoco G (2018) Geochemical sources of vanadium in soils: Evidences in a southern Italy area. J Geochemical Explor 184:358-364. https://doi.org/10.1016/j.gexplo.2016.11.017

29. Hendryx M, Wang S, Romanak KA, Salamova A, Venier M (2020) Personal exposure to polycyclic aromatic hydrocarbons in Appalachian mining communities. Environ Pollut 257:113501. https://doi.org/10.1016/j.envpol.2019.113501

30. Hindersmann B, Achten C (2018) Urban soils impacted by tailings from coal mining: PAH source identification by 59 PAHs, BPCA and alkylated PAHs. Environ. Pollut. 242, 1217-1225. https://doi.org/10.1016/j.envpol.2018.08.014

31. Journel A, Huijbregts C (1978) Mining geostatistics. San Diego: Academic Press.

32. Kalf DF, Crommentuijn T, van de Plassche EJ (1997) Environmental Quality Objectives for 10 Polycyclic Aromatic Hydrocarbons (PAHs). Ecotoxicol Environ Saf 36:89-97. https://doi.org/10.1006/eesa.1996.1495

33. Katsoyiannis A, Terzi E, Cai QY (2007) On the use of PAH molecular diagnostic ratios in sewage sludge for the understanding of the PAH sources. Is this use appropriate? Chemosphere 69:1337- 
1339. https://doi.org/10.1016/j.chemosphere.2007.05.084

34. Keegan TJ, Farago ME, Thornton I, Hong B, Colvile RN, Pesch B, Jakubis P, Nieuwenhuijsen MJ (2006). Dispersion of as and selected heavy metals around a coal-burning power station in central Slovakia. Sci Total Environ 358(1-3):61-71. https://doi.org/1016/j.scitotenv.2005.03.020

35. Kim AW, Vane CH, Moss-Hayes V, Engelhart SE, Kemp AC (2018) PAH, PCB, TPH and mercury in surface sediments of the Delaware River Estuary and Delmarva Peninsula, USA. Mar Pollut Bull 129:835-845. https://doi.org/10.1016/j.marpolbul.2017.10.008

36. Kruge MA, Gallego JR, Lara-Gonzalo A, Esquinas N (2018) Environmental forensics study of crude oil and petroleum product spills in coastal and oilfield settings: Combined insights from conventional GC-MS, thermodesorption-GC-MS and pyrolysis-GC-MS, in: Stout, S.A., Wang, Z. (Eds.), Oil Spill Environmental Forensics Case Studies. Butterworth-Heinemann (Elsevier), United States/United Kingdom, 131-155. https://doi.org/10.1016/B978-0-12-804434-6.00007-0

37. Ladysz J (2006) Chosen aspects of sustainable development on the Polish, Czech and German borderland. GeoJournal 67:1-7. https://doi.org/10.1007/s10708-006-9002-7

38. Li J, Sun C (2016) Evaluation of the migration of thallium, cadmium, vanadium, and chromium from a thermal power plant. Environ. Earth Sci. 75:388. https://doi.org/10.1007/s12665-015-5159-z

39. Liang J, Feng C, Zeng G, Gao X, Zhong M, Li X, Li X, He X, Fang Y (2017) Spatial distribution and source identification of heavy metals in surface soils in a typical coal mine city, Lianyuan, China. Environ Pollut 225:681-690. https://doi.org/10.1016/j.envpol.2017.03.057

40. Marchant BP, Saby NPA, Arrouays D (2017) A survey of topsoil arsenic and mercury concentrations across France. Chemosphere 181:635-644. https://doi.org/10.1016/j.chemosphere.2017.04.106

41. Martin I, Merrington G, Stutt E (2017) Derivation and use of soil screening values for assessing ecological risks. Environ Agency. https://doi.org/10.13140/RG.2.2.35377.68962

42. Martínez J, Saavedra Á, García-Nieto PJ, Piñeiro JI, Iglesias C, Taboada J, Sancho J, Pastor J (2014) Air quality parameters outliers detection using functional data analysis in the Langreo urban area (Northern Spain). Appl Math Comput 241:1-10. https://doi.org/10.1016/j.amc.2014.05.004

43. Matheron G (1971) The Theory of Regionalized Variables and Its Applications, in: Les Cahiers Du Centre de Morphologie Mathématique, No. 5. Ecole des Mines de Paris.

44. Meeker WQ, Hahn GJ, Escobar LA (2017) Statistical Intervals, Wiley Series in Probability and Statistics. John Wiley \& Sons, Inc., Hoboken, NJ, USA. https://doi.org/10.1002/9781118594841

45. Menzie CA, Potocki BB, Santodonato J (1992) Exposure to carcinogenic PAHs in the environment. Environ Sci Technol 26:1278-1284. https://doi.org/10.1021/es00031a002 
46. Megido L, Suárez-Peña B, Negral L, Castrillón L, Fernández-Nava (2017). Suburban air quality: Human health hazard assessment of potentially toxic elements in PM10. Chemosphere 177:284-291. https://doi.org/10.1016/j.chemosphere.2017.03.009

47. Mihailović A, Budinski-Petković L, Popov S, Ninkov J, Vasin J, Ralević NM, Vučinić Vasić M (2015) Spatial distribution of metals in urban soil of Novi Sad, Serbia: GIS based approach. J. Geochemical Explor. 150:104-114. https://doi.org/10.1016/j.gexplo.2014.12.017

48. Ministry of Environment of New Zealand (2001) Guidelines for Assessing petroleum Hydrocarbon Contaminated Sites in New Zealand.

49. Morillo E, Romero AS, Maqueda C, Madrid L, Ajmone-Marsan F, Grcman H, Davidson CM, Hursthouse AS, Villaverde J (2007). Soil pollution by PAHs in urban soils: a comparison of three European cities. J Environ Monit 9:1001. https://doi.org/10.1039/b705955h

50. Murtagh F, Legendre P (2014). Ward's Hierarchical Agglomerative Clustering Method: Which Algorithms Implement Ward's Criterion? J Classif 31:274-295. https://doi.org/10.1007/s00357-0149161-z

51. Nadal M, Schuhmacher M, Domingo JL (2004) Levels of PAHs in soil and vegetation samples from Tarragona County, Spain. Environ Pollut 132:1-11. https://doi.org/10.1016/j.envpol.2004.04.003

52. Nádudvari Á, Fabiańska MJ, Marynowski L, Kozielska B, Konieczyński J, Smołka-Danielowska D, Ćmiel S (2018) Distribution of coal and coal combustion related organic pollutants in the environment of the Upper Silesian Industrial Region. Sci Total Environ 628-629:1462-1488. https://doi.org/10.1016/j.scitotenv.2018.02.092

53. Negral L, Suárez-Peña B, Zapico E, Fernández-Nava Y, Megido L, Moreno J, Marañón E, Castrillón L (2020) Anthropogenic and meteorological influences on PM10 metal/semi-metal concentrations: Implications for human health. Chemosphere 243:125347. https://doi.org/10.1016/j.chemosphere.2019.125347

54. Nguyen TC, Loganathan P, Nguyen TV, Vigneswaran S, Kandasamy J, Slee D, Stevenson G, Naidu R (2014) Polycyclic aromatic hydrocarbons in road-deposited sediments, water sediments, and soils in Sydney, Australia: Comparisons of concentration distribution, sources and potential toxicity. Ecotoxicol Environ Saf 104:339-348. https://doi.org/10.1016/j.ecoenv.2014.03.010

55. Official Journal of the European Communities, 2013. Directive No 2013/39/EU of theEuropean Parliament and of the Council of 12 August 2013 Amending Directives 200/60/EC and 2008/105/EC as Regards Priority Substances in the Field of Water Policy.

56. Padula AM, Balmes JR, Eisen EA, Mann J, Noth EM, Lurmann FW, Pratt B, Tager IB, Nadeau K, Hammond SK (2015) Ambient polycyclic aromatic hydrocarbons and pulmonary function in children. 
J Expo Sci Environ Epidemiol 25:295-302. https://doi.org/10.1038/jes.2014.42

57. Peters KE, Walters CC, Moldowan JM (2005) The Biomarker Guide. Vol. 2. Biomarkers and Isotopes in Petroleum Exploration and Earth History. Cambridge University Press, Cambridge, 1155 p.

58. Pies C, Hoffmann B, Petrowsky J, Yang Y, Ternes TA, Hofmann T (2008) Characterization and source identification of polycyclic aromatic hydrocarbons (PAHs) in river bank soils. Chemosphere 72:1594-1601. https://doi.org/10.1016/j.chemosphere.2008.04.021

59. Prada-Trigo J (2014) Urban decay, strategies revitalization and actor networks: Weight local trajectories through case study Langreo and Avilés (Spain). Revista Geográfica Norte Grande 57:3351. https://doi.org/10.4067/S0718-34022014000100004

60. Querol X, Viana M, Alastuey F, Amato F, Moreno T, Castillo S, Pey J, de la Rosa J, Sánchez de la Campa A, Artíñano B, Salvador P, García dos Santos S, Fernández-Patier R, Moreno-Grau S, Negral L, Minguillón MC, Monfort E, Gil JI, Inza A, Ortega LA, Santamaría JM, Zabalza J (2006). Source origin of trace elements in PM from regional background, urban and industrial sites of Spain Atmos Environ 41:7219-7231. https://doi.org/10.1016/j.atmosenv.2007.05.022

61. Radić S, Medunić G, Kuharić Ž, Roje V, Maldini K, Vujčić V, Krivohlavek A (2018) The effect of hazardous pollutants from coal combustion activity: Phytotoxicity assessment of aqueous soil extracts. Chemosphere 199:191-200. https://doi.org/10.1016/j.chemosphere.2018.02.008

62. Real Decreto $9 / 2005$, de 14 de enero, por el que se establece la relación de actividades potencialmente contaminantes del suelo y los criterios y estándares para la declaración de suelos contaminados.

63. Reimann C, de Caritat P (2005) Distinguishing between natural and anthropogenic sources for elements in the environment: regional geochemical surveys versus enrichment factors. Sci Total Environ 337:91-107. https://doi.org/10.1016/j.scitotenv.2004.06.011

64. Richter-Brockmann S, Achten C (2018) Analysis and toxicity of 59 PAH in petrogenic and pyrogenic environmental samples including dibenzopyrenes, 7H-benzo[c]fluorene, 5-methylchrysene and 1methylpyrene. Chemosphere 200:495-503. https://doi.org/10.1016/j.chemosphere.2018.02.146

65. Rocha AC, Palma C (2019) Source identification of polycyclic aromatic hydrocarbons in soil sediments: Application of different methods. Sci Total Environ 652:1077-1089. https://doi.org/10.1016/j.scitotenv.2018.10.014

66. San José R, Pérez JL, Callén MS, López JM, Mastral A (2013). BaP (PAH) air quality modelling exercise over Zaragoza (Spain) using an adapted version of WRF-CMAQ model. Environ Pollut 183:151-158. https://doi.org/10.1016/j.envpol.2013.02.025 
67. Schobert HH, Song C (2002) Chemicals and materials from coal in the 21st century. Fuel 81:15-32. https://doi.org/10.1016/S0016-2361(00)00203-9

68. Sprovieri M, Feo ML, Prevedello L, Manta DS, Sammartino S, Tamburrino S, Marsella E (2007) Heavy metals, polycyclic aromatic hydrocarbons and polychlorinated biphenyls in surface sediments of the Naples harbour (southern Italy). Chemosphere 67:998-1009.

https://doi.org/10.1016/j.chemosphere.2006.10.055

69. Swartjes F, D'Alessandro M, Carlon C (2007) Variability of soil screening values, in: Derivation Methods of Soil Screening Values in Europe. A Review and Evaluation of National Procedures towards Harmonisation. pp. 58-73.

70. Thavamani P, Megharaj M, Naidu R (2012) Multivariate analysis of mixed contaminants (PAHs and heavy metals) at manufactured gas plant site soils. Environ Monit Assess 184:3875-3885. https://doi.org/10.1007/s10661-011-2230-4

71. Thiombane M, Albanese S, Di Bonito M, Lima A, Zuzolo D, Rolandi R, Qi S, De Vivo B (2019) Source patterns and contamination level of polycyclic aromatic hydrocarbons (PAHs) in urban and rural areas of Southern Italian soils. Environ Geochem Health 41:507-528. https://doi.org/10.1007/s10653-018-0147-3

72. Tissot BP, Welte DH (1984) Petroleum Formation and Occurrence. Springer, 702.

73. Tobiszewski M, Namieśnik J (2012) PAH diagnostic ratios for the identification of pollution emission sources. Environ Pollut 162:110-119. https://doi.org/10.1016/j.envpol.2011.10.025

74. Vane CH, Kim AW, Beriro DJ, Cave MR, Knights K, Moss-Hayes V, Nathanail PC (2014) Polycyclic aromatic hydrocarbons (PAH) and polychlorinated biphenyls (PCB) in urban soils of Greater London, UK. Appl Geochemistry 51:303-314. https://doi.org/10.1016/j.apgeochem.2014.09.013

75. Wang C, Wang J, Zhou S, Tang J, Jia Z, Ge L, Li Y, Wu S (2020) Polycyclic aromatic hydrocarbons and heavy metals in urban environments: Concentrations and joint risks in surface soils with diverse land uses. L Degrad Dev 31:383-391. https://doi.org/10.1002/ldr.3456

76. Wilcke W (2007) Global patterns of polycyclic aromatic hydrocarbons (PAHs) in soil. Geoderma 141:157-166. https://doi.org/10.1016/j.geoderma.2007.07.007

77. Wu S, Zhou S, Bao H, Chen D, Wang C, Li B, Tong G, Yuan Y, Xu B (2019) Improving risk management by using the spatial interaction relationship of heavy metals and PAHs in urban soil. $J$ Hazard Mater 364:108-116. https://doi.org/10.1016/j.jhazmat.2018.09.094

78. Yan J, Wang L, Fu PP, Yu H (2004) Photomutagenicity of 16 polycyclic aromatic hydrocarbons from the US EPA priority pollutant list. Mutat Res Toxicol Environ Mutagen 557:99-108. https://doi.org/10.1016/j.mrgentox.2003.10.004 
79. Yunker MB, Macdonald RW, Vingarzan R, Mitchell RH, Goyette D, Sylvestre S (2002) PAHs in the Fraser River basin: a critical appraisal of PAH ratios as indicators of PAH source and composition. Org Geochem 33:489-515. https://doi.org/10.1016/S0146-6380(02)00002-5

80. Zhang W. Zhang S, Wan C, Yue D, Ye Y, Wang X (2008) Source diagnostics of polycyclic aromatic hydrocarbons in urban road runoff, dust, rain and canopy throughfall. Environ Pollut 153:594-601. https://doi.org/10.1016/j.envpol.2007.09.004

\section{Figures}

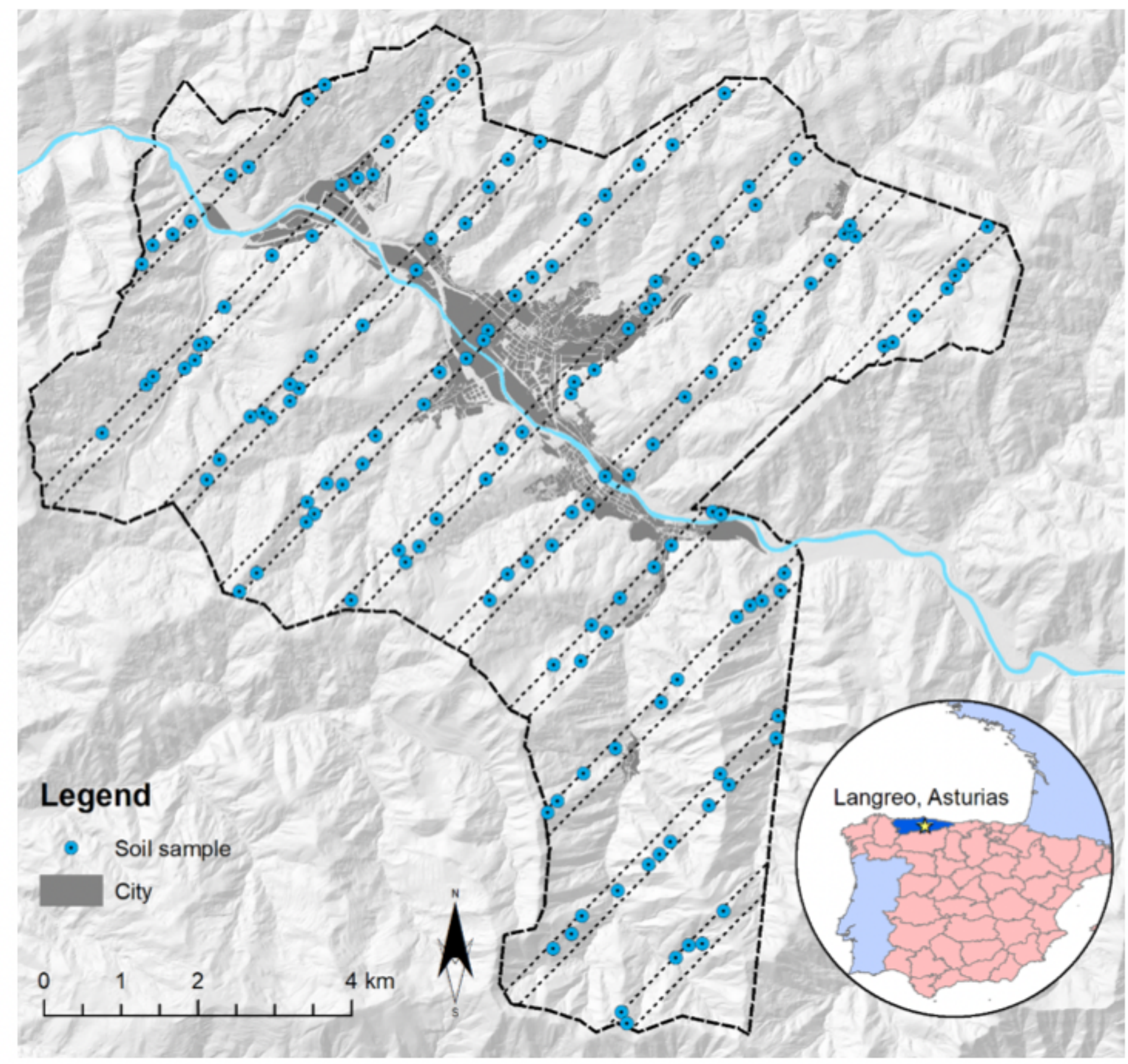


Figure 1

Location of the study area in Spain and sampling design.

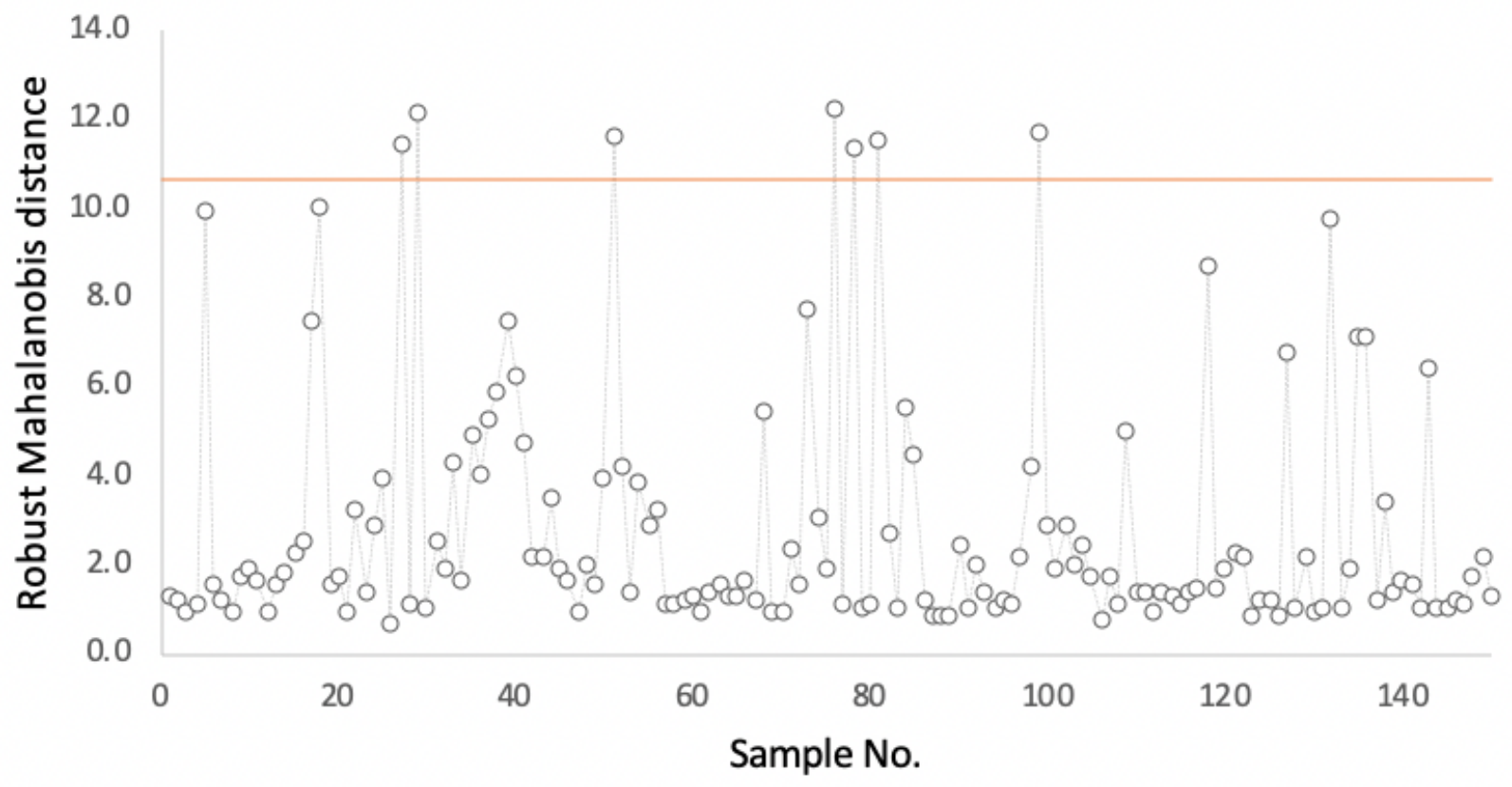

Figure 2

Robust Mahalanobis distance for the PAH data matrix of the Langreo soils. The horizontal line corresponds to the cut-off value equal to percentile 95 of the Mahalanobis distance. Samples over the line were considered outliers. 


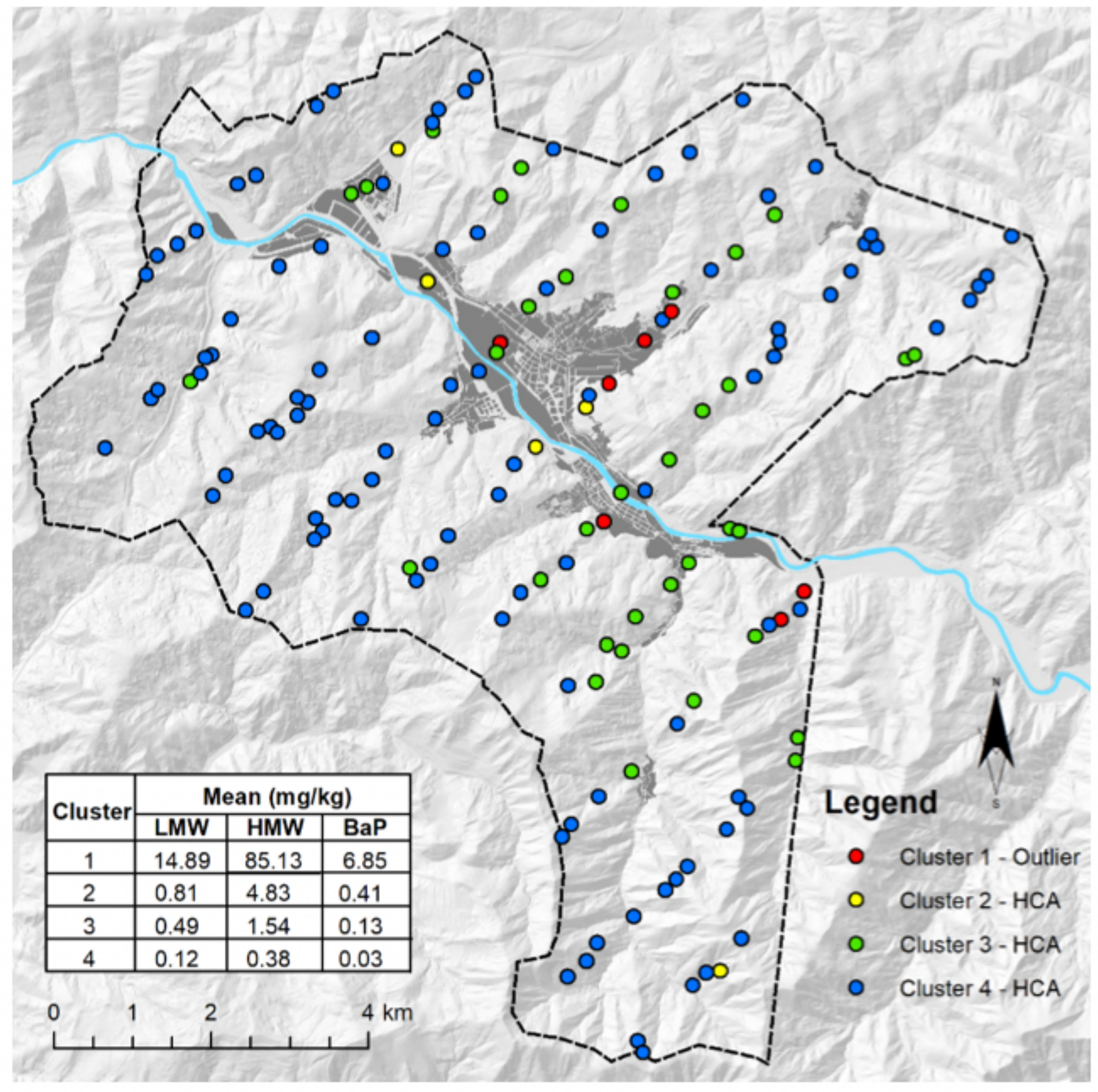

Figure 3

Graphical clustering and mean concentration of LMW and HMW PAHs and BaP for each cluster. 


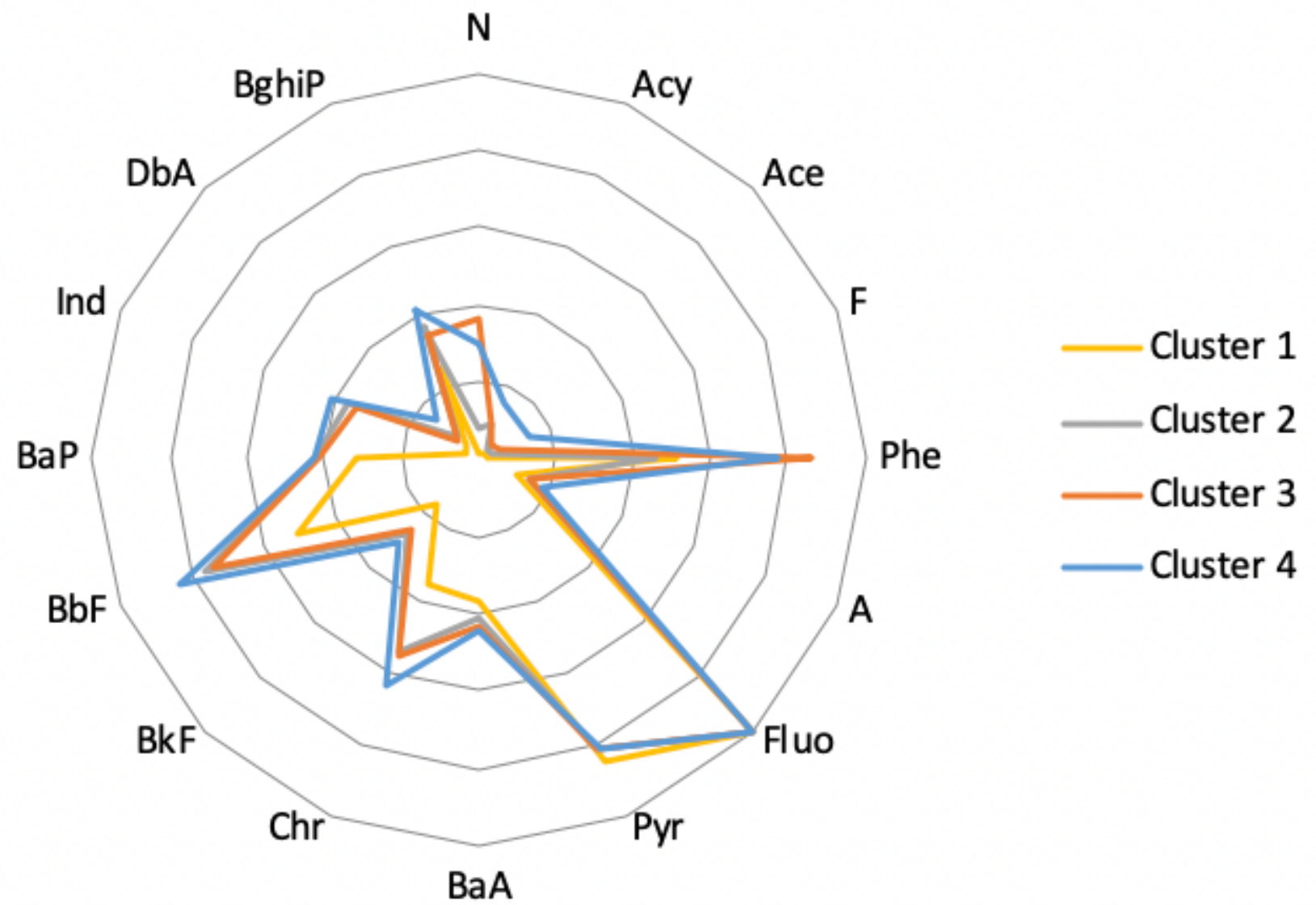

Figure 4

Parent-PAH distribution (\% normalized) for the mean concentration of individual PAHs in the four clusters obtained after outlier detection and HCA. 

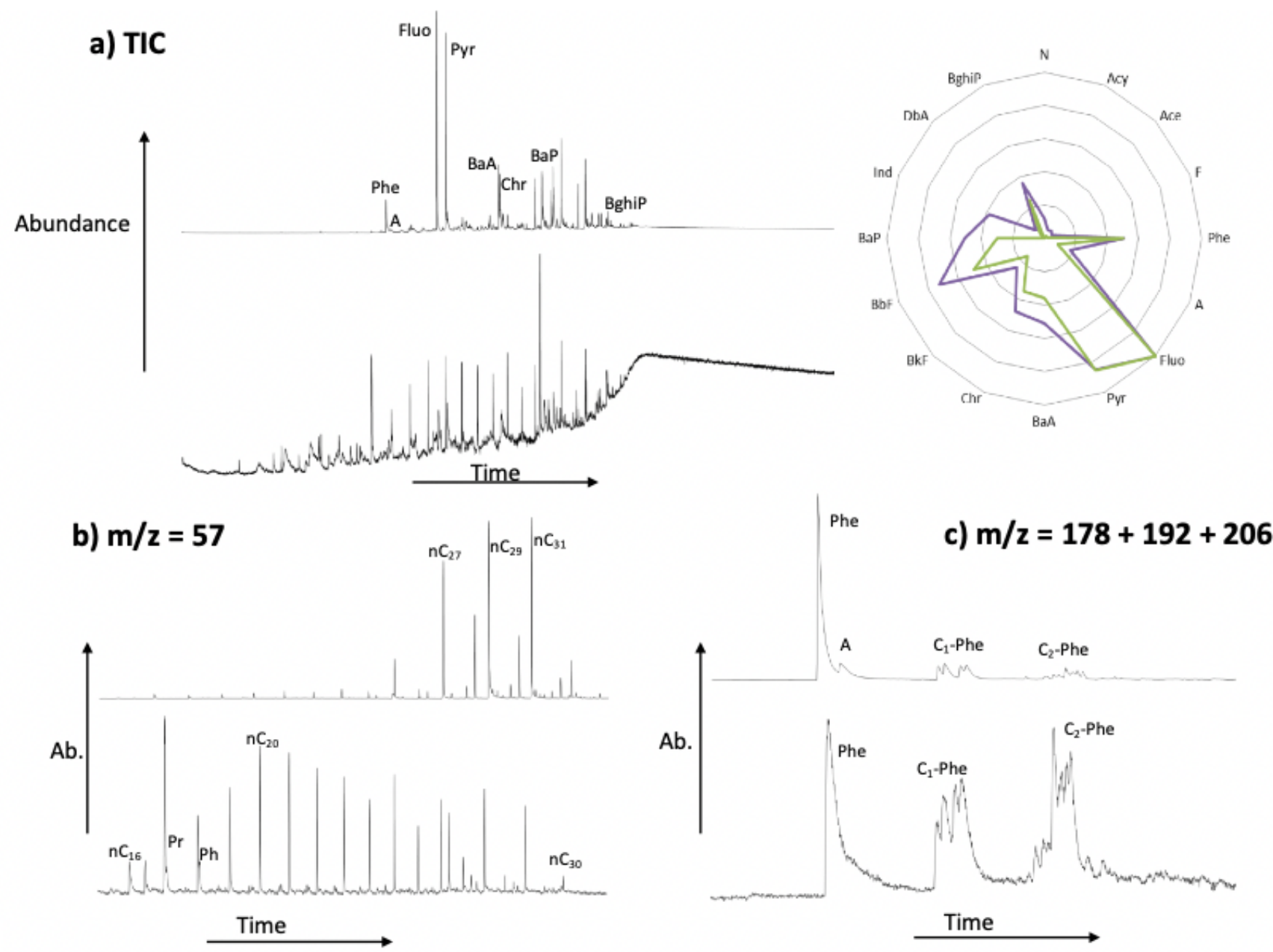

\section{Figure 5}

a) Total Ion Chromatograms (TIC) of two outliers, the first one (top) showing a typical fingerprint of a coal-tar derivative (PAHs predominant), and the second (bottom) a petroleum product (lubricant oil, fuel oil or similar with n-alkanes predominant). The PAH star diagram (right) does not reflect many differences between the samples. (b) Single lon Monitoring (SIM) chromatogram (m/z 57) of the same samples revealing only some high-molecular weight odd numbered n-alkanes in the first case and a complete series of n-alkanes and isoprenoids in the second. (c) Merged SIM (m/z = 178, 192 and 206 respectively) chromatograms for phenanthrene and alkyl derivatives (both C1- and C2-) (m/z = 178, 192 and 206 respectively, note the predominance of the parent PAH over the substituted compounds (top) and the inverse situation (bottom). Phe: Phenanthrene; A: Anthracene; Fluo: Fluoroanthene; Pyr: Pyrene; BaA: Benzoanthracene; Chr: Chrysene; BghiP: Benzoperylene; Pr, pristane; Ph, phytane; nCn: n-alkanes; C1-Phe: Methyl phenanthrenes; C2-Phe: Dimethyl phenanthrenes.

\section{Figure 6}


a) Ordinary kriging (OK) results and experimental variograms for BaP concentration in soils. Shaded areas correspond to the city. b) 3D representation over Digital Terrain Model (DTM). 